\title{
Parametric Land Suitability Assessment for Rainfed Agriculture: The Case of Bilate Alaba Sub-watershed, Southern Ethiopia
}

\section{Markos Mathewos ${ }^{1^{*}}$, Mihret Dananto ${ }^{2}$, Teklu Erkossa ${ }^{3}$ and Getachew Mulugeta ${ }^{4}$}

${ }^{1}$ School of Plant and Horticulture Science, Hawassa University, Ethiopia

${ }^{2}$ School of Biosystems and Environmental Engineering, Hawassa University, Ethiopia

3 Internationale Zusammenarbeit (GIZ) GmbH, Ethiopia

${ }^{4}$ College of Agriculture and Natural resources, Dilla University, Ethiopia

\begin{abstract}
The natural resources are becoming scanty in developing country like Ethiopia to support over increased human population without deprivation, scientific approach of land suitability is important to make a proper decision for sustainable agricultural development and maximizing the best use of the land resources. With the deliberation of Rainfed conditions of maize, sorghum and wheat, land suitability evaluation was carried out at Bilate Alaba Subwatershed. Uses of maximum limitation and parametric (Storie and Square root) were applied for the determination of land suitability categories of land characteristics. The result showed that climate is highly suitable (S1) for maize whereas moderately suitable (S2) for sorghum and wheat. From total sub-watershed, $2.45 \%$ is marginally suitable (S3) for wheat and $97.55 \%$ is moderately suitable (S2) for maize and sorghum production using FAO land evaluation method whereas offering Storie method, $14.75 \%$ of sub-watershed is marginally suitable (S3) for sorghum and wheat, $85.25 \%$ is moderately suitable (S2) for sorghum and wheat cultivation. Considering maize production under rain-fed conditions, all mapping units were moderately suitable (S2). Parametric Square root result revealed that four soil mapping units were moderately suitable (S2) for maize, wheat and sorghum crops in the sub-watershed. Soil fertility (phosphorus and nitrogen), moisture stress and erosion hazard were the most limiting factors in the sub-watershed. Soil management practices may recover soil fertility with the application of animal manures and household wastes for nitrogen and phosphorus limitations, proper natural resource protection practice to cut the effects of erosion due to topographic features.
\end{abstract}

Keywords: Land evaluation; Suitability; Maximum limitation; Parametric; Limiting factor; Rainfed agriculture

\section{Introduction}

Land evaluation concerned overall land performances which include landforms, climate, vegetation and soils, studies about proper and promising land use types to be applied within course objective of land suitability [1]; it involves system management and specific purpose of the study [2]. Land evaluation is an identification of parcel of land for various land uses (cropping, grazing, and irrigation) which are physically acceptable, environmentally friend and financially profitable [3]; it supports the process of decision-making land to perform based on its potential [4].

Land as a concept that describes the interpretation processes of the principal inventories belonging to soil characteristics, vegetation cover, environmental conditions, climatic status and many other aspects related to the land to identify best land use among its alternatives [5].

There were physical and biochemical complex processes interacted in assessments of land suitability in which evaluation model consistent large enough to forecast the land behavior [6]. FAO approach used the biophysical environments and Socio-economic conditions [7], it was emphasized the estimation of ecosystem productivity for specific land utilization purposes [8]. Land suitability classification is an approach in land evaluation concerning the appraisal in terms of suitability [9]; it is carried out to make an evaluation of the land for the specific use of farming/rainfed or irrigation purposes [10]. In similar way, it is study of certain parts of land appropriateness to specific types of land use [11]. Different scholars [12-15] were conducted concerning land suitability for agriculture in different countries on the basis of FAO land evaluation framework.
There are different approaches to land evaluation, each has different data requirements and various qualities of estimates, however, there are no fixed laws that specify when and any methods are adequate or when there is the need to continue to a more complex analysis level [16]. Ethiopia was categorized under developing countries, qualitative land suitability method was practiced due to limited information regarding data in relation to land resources and financial resources were scarce [17] which is compared with process-oriented model land functions required large data input and more costly. Smallholders usually motivated land use by continuously traditionally farming practices opted to new cropping systems due to other social factors, this contributed to natural resources depletion and degradation [18].

In Ethiopia agriculture, major cereals maize, wheat and sorghum have been essential crops and contributed to food security in the country [19] mainly produced in most Ethiopian highlands [20]. Agriculture experienced mostly rain-fed subjected to higher seasonal and annually variability which influenced land productivity [21] and resulted in land degradation occurred in most highlands of the country [22].

*Corresponding author: Mathewos M, School of Plant and Horticulture Science Hawassa University, Ethiopia, Tel: +251913737521; E-mail: godebo09@gmail.com

Received October 13, 2018; Accepted December 04, 2018; Published December 11, 2018

Citation: Mathewos M, Dananto M, Erkossa T, Mulugeta G (2018) Parametric Land Suitability Assessment for Rainfed Agriculture: The Case of Bilate Alaba Sub-watershed, Southern Ethiopia. Agrotechnology 7:183. doi: 10.4172/2168 9881.1000183

Copyright: (c) 2018 Mathewos M, et al. This is an open-access article distributed under the terms of the Creative Commons Attribution License, which permits unrestricted use, distribution, and reproduction in any medium, provided the original author and source are credited. 
The Ethiopian government has produced long-term overall economic development policy to achieve industrialization through robust agricultural development to achieve rapid and sustainable economic growth by improving the productivity of the agricultural sector. However, Ethiopian natural resources are the basis for development and economic growth; there were knowledge limitations about utilization and suitability of resources within farmers and other residents.

Arable land reduced since more areas had been under cultivation to feed ever growing population it has reached to stage that difficult to cultivate degraded lands to produce crops [23]. Moreover, continuous soil erosion and forest clearance by rural communities resulted from the rapid population [24] to satisfy food and fuel consumptions depleted natural resources in the sub-watershed, the productivity of land is declining, and marginal lands are being converted to cultivated lands. Farmers in the study area have been cultivating various crops without being assessing the suitability based on land qualities, characteristics and crop requirements, no scientific research conducted in particular place aiming usage of potential sustainability of land management while cultivating crops on their farmlands. Hence, this research was instigated to assess the land suitability of Bilate Alaba sub-watershed for Rainfed wheat, maize and sorghum crops to overcome the limitations.

\section{Materials and Methods}

\section{Description of study area}

Bilate Alaba sub-watershed located in Alaba District, Southern Ethiopia about $310 \mathrm{~km}$ south of Addis Ababa and about $85 \mathrm{~km}$ southwest of the Southern regional state capital of Hawassa. The sub-watershed is geographically located UTM coordinates of 387500 to $413750 \mathrm{~m}$ north latitude and 797000 to 824500 m east longitude (Figure 1).

The elevation ranges from 1613 to 2201 meter above sea level, but the majority of the sub-watershed is found at about 1880 meter above sea level, the sub-watershed coverage estimated is about $403 \mathrm{~km}^{2}$, it is proper for crop production and animal husbandry because of its major portion is flat with regard to its landscape.

The soil in the study area potentially fertile if properly managed through various soil management practices and smallholders can get reasonable yield without application of inorganic fertilizers. The nature of the soil in the study area have been detached by both water and wind resulted from the development of huge gullies in the northern and eastern parts; in some north-eastern part it was totally removed and degraded by the effects of cattle and human interference of the natural ecosystem [25].

Agro-ecologically, the sub-watershed is characterized as Subtropical zone having the mean precipitation of $1093 \mathrm{~mm}$ per year and the average annual temperature value of $21^{\circ} \mathrm{C}$. It has received bimodal rainfall where the main rainfalls are from July to October whereas small rains are between March and April. Rainfalls in both seasons were erratic unevenly distributed resulted in crop failures in most parts of the sub-watershed (Figure 2).

Maize, sorghum, wheat, pepper and haricot beans are the common rain-fed crops grown in the area. All these crops are managed using traditional agricultural techniques and equipment. Moreover, a few types of vegetables and livestock feed like rodus grass and cowpea are grown with the help of small irrigation scheme [25]. The population of livestock exceeded the available feed sources in the sub- watershed has affected animal production in existing crop-livestock farming systems.
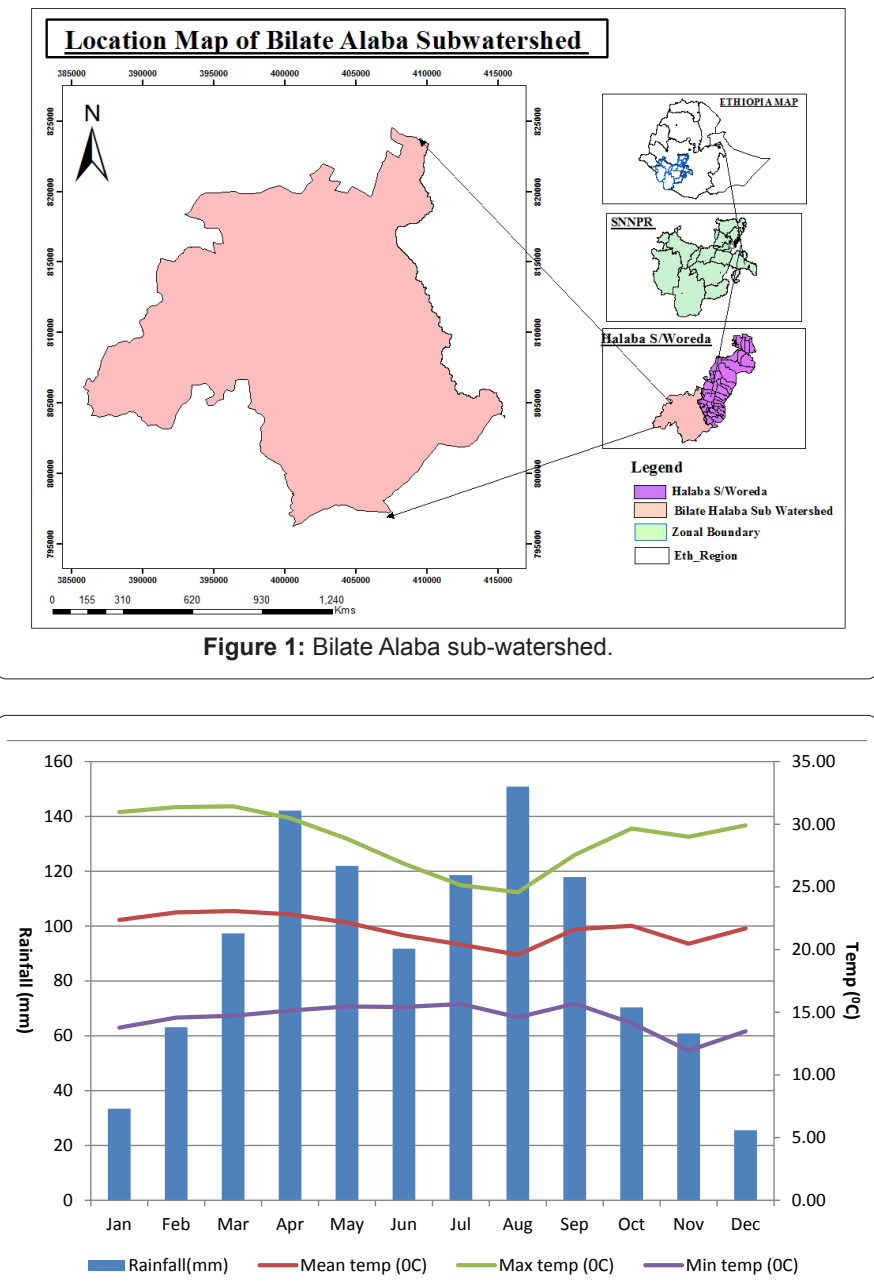

Figure 2: Average monthly precipitation and temperature (minimum, maximum \& mean) of Bilate Alaba areas from 1984 to 2015 G.C.

There are four major soil types (Andosol, Luvisol, Phaeozem and Nitosol) exist in the sub-watershed according to the FAO soil classification [26]. They are considered as soil mapping unit (SMU) for this research. 3-5 sampling sites selected in every soil types depending on soil texture and depth based on area coverage. 42 soil samples were collected from the surface layer $(0-30 \mathrm{~cm})$ by using auger and were bulked into 14 composite soil samples for the purpose of land evaluation for major selected three crops (Figure 3 ). Moreover, four pedons, each of having $(2 \mathrm{~m} \times 2 \mathrm{~m} \times 1.5 \mathrm{~m})$ soil pit was excavated at each soil types in the study area, representative soil samples from each horizon were collected for further laboratory analysis.

\section{Laboratory analysis for soils}

The soil samples were air dried and passed through a 2-mm sieve for the analysis of chemical properties using a systematic technique. The soil $\mathrm{pH}$ was measured using a glass combination $\mathrm{pH}$ meter in the supernatant suspension of 1:2.5 (soil: water) solution ratio. The organic carbon (OC) was determined by wet digestion method [27]. The Kjeldahl procedure was followed by for the measurement of total nitrogen (TN) as described by [28]. The available phosphorus content of the soils was analyzed using the sodium bicarbonate extraction solution at $\mathrm{pH} 8.5$ by [29]. Hydrometer method was employed for the determination of soil texture [30]. All soil samples were passed through 


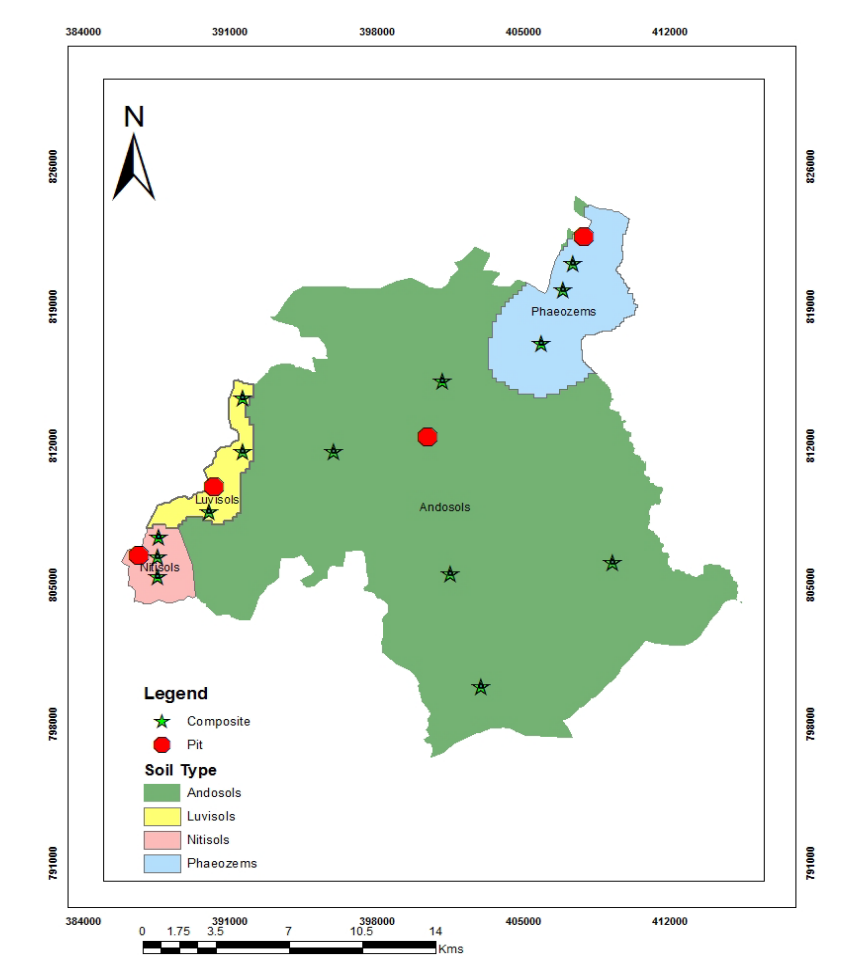

Figure 3: Pit and composite sampling sites.

$0.5 \mathrm{~mm}$ sieve for measurement of organic carbon and total nitrogen cation exchange capacity of the soil was determined from ammonium acetate saturated sample; the excess ammonium acetate was removed by washing with ethanol [31]. The electrical conductivity (EC) of soils was measured by electrical conductivity meter as described by [32].

The exchangeable basic cations $\left(\mathrm{K}^{+}, \mathrm{Ca}^{2+}, \mathrm{Mg}^{2+}\right.$, and $\left.\mathrm{Na}^{+}\right)$was extracted with $1 \mathrm{M}$ ammonium acetate at $\mathrm{pH}$ 7.0 [33]. Exchangeable $\mathrm{Ca}^{2+}$ and $\mathrm{Mg}^{2+}$ in the extracts was analyzed using atomic absorption spectrophotometer (AAS), while $\mathrm{Na}^{+}$and $\mathrm{K}^{+}$were determined by flame photometer. Exchangeable sodium percentage in order to determine soil alkalinity can be computed as presented in equation 1

$$
E S P=\frac{\text { Exchangable }[\mathrm{Na}]}{[\mathrm{CEC}]} \times 100
$$

Where ESP exchangeable sodium percentage, CEC cation exchange capacity

\section{Description of soil mapping units}

Soil mapping unit one (SMU1): It has a gentle slope with the topography with slope of $5 \%$, well-drained having deep effective soil depth $(>150$ $\mathrm{cm}$ ), it has texture varied from clay, silty clay loam, clay loam, sandy loam and loam throughout the mapping unit under study. The mapping unit was has $\mathrm{pH}$ ranged from 6.55-7.93, free from salinity $\left(<1 \mathrm{dsm}^{-1}\right)$, low in OC (2.54\%-3.9\%), the TN was varied $0.02-0.026 \%$ content, low to high in available $\mathrm{P}\left(5.5-28.40 \mathrm{mgkg}^{-1}\right)$, exchangeable $\mathrm{Ca}$ (11.74-17.00 $\left.\mathrm{cmol}(+) \mathrm{kg}^{-1}\right)$ and $\mathrm{Mg}\left(3.37-6.81 \mathrm{cmol}^{(+)} \mathrm{kg}^{-1}\right)$, high to very high CEC (34.00-48.00 $\left.\mathrm{cmol}(+) \mathrm{kg}^{-1}\right)$ and high ESP (5.89\%-19.39\%).

Soil mapping unit two (SMU2): It has slope of ranged from $8 \%$ $14 \%$, soil depth was greater than $100 \mathrm{~cm}$, moderately well drained, it has texture varied from clay, silty clay loam and clay loam throughout the mapping unit under study. The unit was $\mathrm{pH}\left(\mathrm{H}_{2} \mathrm{O}\right)$ wide-ranging from 6.30 to 6.66 , free from salinity $\left(<1 \mathrm{dsm}^{-1}\right)$, low to medium in OC (2.09\%-4.58\%), very low to low in TN (0.08\%-0.19\%) content, high available $\mathrm{P}$ (16.3-32.34 $\left.\mathrm{mgkg}^{-1}\right)$ content, exchangeable $\mathrm{Ca}$ (15.27-22.59 $\left.\mathrm{cmol}(+) \mathrm{kg}^{-1}\right)$ and $\mathrm{Mg}\left(4.69-4.94 \mathrm{cmol}(+) \mathrm{kg}^{-1}\right)$ dominated exchange complex, very high CEC (43.5-46.0 $\left.\mathrm{cmol}(+) \mathrm{kg}^{-1}\right)$ and low ESP (3.68\%$4.29 \%)$.

Soil mapping unit three (SMU3): It has slope of $12 \%$, deep soil depth $(>120 \mathrm{~cm})$, moderately well-drained soil, and the unit texture is varied from loam to clay loam. The mapping unit was slightly acidic in $\mathrm{pH}$ (6.44-6.46), free from salinity $\left(<1 \mathrm{dsm}^{-1}\right)$, low to medium in OC (3.32\%-4.78\%) and low in TN (0.11\%-0.18\%) content, medium to high available $\mathrm{P}$ (12.3-28.2 $\left.\mathrm{mg} \mathrm{kg}^{-1}\right)$ content, exchangeable $\mathrm{Ca}$ (12.41-12.44 $\left.\mathrm{cmol}(+) \mathrm{kg}^{-1}\right)$ and $\mathrm{Mg}\left(2.80-7.79 \mathrm{cmol}(+) \mathrm{kg}^{-1}\right)$ dominated exchange complex, high in divalent $(\mathrm{Ca}$ and $\mathrm{Mg})$ and moderate in monovalent ( $\mathrm{Na}$ and $\mathrm{K}$ ) exchangeable basic cations, very high CEC (45.80-46.40 $\mathrm{cmol}(+) \mathrm{kg}^{-1}$ ) and low ESP (4.09\%-12.18\%).

Soil mapping unit four (SMU4): It has a slope of $18 \%$, having soil depth greater than $100 \mathrm{~cm}$, in terms of drainage categorized as moderately well-drained, and clay loam to loam in texture. The mapping unit was very slightly acidic to slightly alkaline in $\mathrm{pH}(6.70-$ $7.52)$, free from salinity $\left(<1 \mathrm{dsm}^{-1}\right)$, low in OC $(2.09 \%-2.93 \%)$ and very low to low in TN $(0.02 \%-0.20 \%)$ content, medium to high available $\mathrm{P}$ (13.70-18.80 $\left.\mathrm{mgkg}^{-1}\right)$ content, exchangeable $\mathrm{Ca}(14.20-16.36 \mathrm{cmol}(+)$ $\left.\mathrm{kg}^{-1}\right)$ and $\mathrm{Mg}\left(5.76-6.70 \mathrm{cmol}(+) \mathrm{kg}^{-1}\right)$ dominated exchange complex, high in divalent $(\mathrm{Ca}$ and $\mathrm{Mg}$ ) and moderate in monovalent $(\mathrm{Na}$ and $\mathrm{K})$ exchangeable basic cations, very high CEC (46.0-52.00 $\left.\mathrm{cmol}(+) \mathrm{kg}^{-1}\right)$ and ESP (3.40\%-16.23\%).

\section{Land utilization types and their requirements}

Growing of maize, wheat and sorghum with their growing period with the aid of rainfall condition was identified as land utilization types (LUT) reckoned. Land suitability's for maize (Zea mays), wheat (Triticum aestivum L.) and sorghum (Sorghum bicolor) were evaluated using [9,34]. With the involvement of District agriculture experts, focus group discussions and consultation of lead farmers in the subwatershed LUTs were identified. Economic importance priorities in the rural communities' livelihood, past experience of crop cultivation history and suitability soil types were taken as crop selection criteria [9]. The land use and crop requirements for each LUT were assessed with desk review, preliminary reports and different publications $[2,35$ 41].

The agro-climate requirements for selected LUT were temperature $\left(0^{\circ} \mathrm{C}\right)$, rainfall $(\mathrm{mm})$ and length of growing periods (days). The slope was taken as topography feature while soil characteristics considered were drainage condition, texture, soil depth $(\mathrm{cm}), \mathrm{pH}$, organic carbon (\%), CEC $\left(\mathrm{cmol}(+) \mathrm{kg}^{-1}\right)$, total nitrogen (\%), available phosphorus $\left(\mathrm{mgkg}^{-1}\right)$ of topsoil. The soil salinity and alkalinity were regarded as part of soil characteristics.

\section{Agro-climatic analysis}

Accurate comparison of precipitation with potential evapotranspiration (ETo) was made to estimate the length of growing period (LGP) for the major crops under the study [35]. The climatic data namely temperature (mean, maximum and minimum) and precipitation collected from the national meteorological agency from 1984-2015, they were used to make a possible estimation of ETo using Penman-Monteith approach [42]. 
Linear interpolation method deployed to estimate the end as well as start-up of growing period which relied on the data of both precipitation and ETo [35]. When a precipitation exceeds half of potential evapotranspiration crop growing season could initiate correspondingly, ending of precipitation season to be found when the total precipitation is fewer than partly corresponding ETo. With regard to the humid period determination procedure similar approach is used as discussed earlier [2,35].

\section{Land suitability maps using maximum and parametric methods}

Among different land characteristics having lower class values determined land suitability class as per the FAO method particularly maximum limitation procedure $[35,36]$ by matching selected crop requirements with measured environmental/landscape and soil parameters under the study, the land suitability maps of 4 soil mapping units were produced with the aid of computer program Arc GIS 10.1 software.

Parametric method: Land evaluation in parametric method considered various soil and landscape characteristics used numerical scales ranged from $0 \%$ attributes have certain limitation, gets a low rate up to $100 \%$ maximum rate appropriate for a crop, the parametric approach used two different procedures: The Storie method, this index was obtained as a multiplicative of each characteristic [43], mathematically it is expressed in equation 2 as follows:

$$
I=A \times \frac{B}{100} \times \frac{C}{100} \times \frac{X}{100} \times \ldots
$$

Where I is Storie index (\%) and A, B, C etc. expressed various soil characteristics (\%).

Square root method: Square root method was introduced by [44] which take into consideration the entire land characteristic, but important consideration is given for most limiting factor least scored value among the parameters. Mathematically it is represented by the following equation 3, after determining land index, land suitability classes were determined according to [2].

$$
I=R \min \times \sqrt{\left(\frac{A}{100} \times \frac{B}{100} \times \frac{C}{100} \times \ldots\right)}
$$

Where, $\mathrm{I}$ is land index, Rmin the minimum rating between different soil properties and $\mathrm{A}, \mathrm{B}, \mathrm{C}$ is other characteristic ratings without the minimum rating assigned.

\section{Results}

\section{Climatic land suitability}

Based on linear analysis of climatic inputs, the length of growing period was 197 days; April 10 and November 3 were the start and end of growing period, while June 9 and September 15 respectively were start and end of the humid period (Figure 4).

Under the rainfed agriculture scenario, climate is highly suitable (S1) for maize crop while moderately suitable (S2) for sorghum and wheat cultivation (Table 1). Mean temperature and LGP were the major limiting factors for sorghum and wheat in the sub-watershed. Moreover, rainfall is the other limiting factor which has influenced the growth of sorghum crop in the study area (Table 1). In a similar manner, using parametric method (Storie and Square root) climate is highly suitable (S1) for maize production whereas moderately suitable (S2) for sorghum

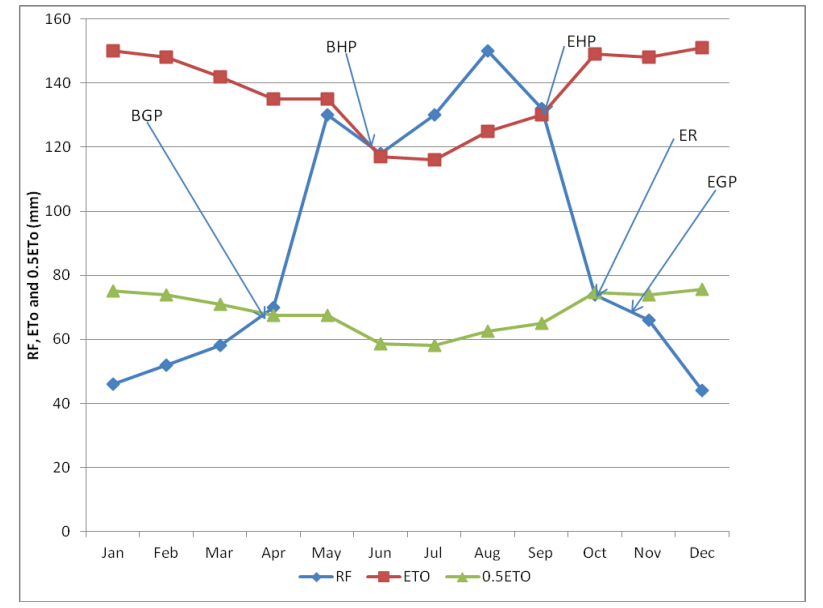

Figure 4: LGP of Bilate Sub-watershed, Southern Ethiopia.

\begin{tabular}{|c|c|c|c|c|}
\hline \multirow{2}{*}{$\begin{array}{c}\text { Climatic } \\
\text { charaterstics }\end{array}$} & & \multicolumn{3}{|c|}{ Crops } \\
\cline { 2 - 5 } & Value & Maize & Sorghum & Wheat \\
\hline MeanTemperature $\left({ }^{\circ} \mathrm{C}\right)$ & 21.6 & $\mathrm{~S} 1$ & $\mathrm{~S} 2$ & $\mathrm{~S} 2$ \\
\hline Length of growing period (day) & 197 & $\mathrm{~S} 1$ & $\mathrm{~S} 2$ & $\mathrm{~S} 2$ \\
\hline Percipitation(mm) & 1102 & $\mathrm{~S} 1$ & $\mathrm{~S} 2$ & $\mathrm{~S} 1$ \\
\hline suitability & & $\mathrm{S} 1$ & $\mathrm{~S} 2$ & $\mathrm{~S} 2$ \\
\hline
\end{tabular}

Table 1: Climatic suitability for maize, wheat and sorghum cultivation by FAO

\begin{tabular}{|c|c|c|c|c|}
\hline \multirow{2}{*}{$\begin{array}{c}\text { Climatic } \\
\text { characterstics }\end{array}$} & \multirow[b]{2}{*}{ Value } & \multicolumn{3}{|c|}{ Crops } \\
\hline & & Maize & Sorghum & Wheat \\
\hline MeanTemperature $\left({ }^{\circ} \mathrm{C}\right)$ & 21.6 & 95 & 85 & 85 \\
\hline $\begin{array}{l}\text { Length of growing period } \\
\text { (day) }\end{array}$ & 197 & 95 & 95 & 85 \\
\hline Percipitation(mm) & 1102 & 95 & 85 & 95 \\
\hline Storie index & & 86 & 69 & 69 \\
\hline Square rootindex & & 90 & 75 & 75 \\
\hline Storie result & & $\mathrm{S} 1$ & $\mathrm{~S} 2(\mathrm{~m}, \mathrm{t})$ & $\begin{array}{c}\mathrm{S} 2 \\
(\operatorname{lgp}, \mathrm{t})\end{array}$ \\
\hline Square root & & $\mathrm{S} 1$ & $\mathrm{~S} 2(\mathrm{~m}, \mathrm{t})$ & $\begin{array}{c}\mathrm{S} 2 \\
(\operatorname{lgp}, \mathrm{t})\end{array}$ \\
\hline
\end{tabular}
methods.

Table 2: Climatic suitability for maize, wheat and sorghum cultivation using the parametric method.

and wheat crop with main limiting factors were temperature, LGP and rainfall (Table 2). The sub-watershed had been experienced moisture stress for the last two decades which influenced the crop production. Water is vital to plant growth, so varying precipitation patterns have a significant impact on crop production in the study area, higher growing season temperatures can significantly impact agricultural productivity and food security.

\section{Environmental suitability for maize, sorghum and wheat under rainfed condition based on FAO approach}

Soil mapping unit one (SMU1) is moderately suitable (S2) for maize, sorghum and wheat, higher soil $\mathrm{pH}$ and higher exchangeable sodium percentage were the limiting factors. SMU2 is moderately suitable (S2) for maize, wheat and sorghum (Table 3). The main limiting factors are moderately well drainage, soil depth and topography. Similarly, SMU3 is moderately suitable (S2) for maize, wheat and sorghum. The major limiting factors were moderately well drainage, topography conditions, soil texture, total nitrogen and available phosphorus. 
SMU4 is marginally suitable (S3) for wheat due to slope conditions, moderately suitable for maize and sorghum. The major limiting factors were moderately drainage, topographic features, total nitrogen and phosphorus content (Table 3). Areas having the slope range less than $9 \%$ is optimum for the proper growth of maize, sorghum and wheat productions while field observation and measurements of the slope in the sub-watershed revealed the slope of the SMU4 is exceeds $16 \%$ categorized marginally suitable for the crops. This indicated landscape position has a major effect on crop production and it can be suitable for other land uses mainly forest development to optimize the management of natural resources in the study area, Southern Ethiopia.

\section{Environmental suitability for maize, sorghum and wheat under rainfed condition based on the parametric method}

Both Storie and square root methods obtained were moderately suitable (S2) for maize production in all units. In SMU1 the maize crop was influenced by fertility (nitrogen and phosphorus) and alkalinity (ESP); in SMU2 and SMU3 soil fertility, topographic factors and wetness were a severe limitation, erosion and soil alkalinity were the main influencing factors in SMU4 for maize cultivation. For wheat and sorghum production SMU2, SMU3 and SMU4 were moderately suitable for both methods except SMU2 for wheat production was highly suitable (S1) using square root method. On the contrary, SMU1 is highly suitable (S1) for sorghum and wheat in square root method while moderately suitable (S2) by Storie method for maize and sorghum crop in both methods (Table 4).

Sorghum crop was limited by fertility in SMU1, erosion, wetness and phosphorus in SMU2; topographic features and fertility in SMU3 and SMU4 respectively. Similarly, regarding wheat crop cultivation erosion was the main influencing parameters in all units whereas rooting depth, alkalinity and fertility were other influencing factors in SMU1 (Table 4).

\section{Overall land suitability evaluation}

The land suitability classification result indicated lands currently under rain-fed cultivation, has ranged from moderately suitable to marginally suitable for agricultural purposes in terms of environmental behaviors, unlike climatic suitability. Four soil mapping units used similar climatic data achieved the same climatic suitability.

The unit SMU4 having 987 ha $(2.45 \%)$ of the sub-watershed, is marginally suitable (S3) for wheat (Figure 5 and Table 5) and on the contrary moderately suitable (S2) for maize and sorghum (Figures 6,7 and Table 5), while the remaining mapping units having 34,351 ha $(85.25 \%), 3703$ ha $(9.19 \%)$ and 1255 ha $(3.11 \%)$ of the Sub-watershed, were moderately suitable (S2) for maize, wheat and sorghum production respectively (Table 5 and Figures 5-7). For the production maize, topography, alkalinity and drainage class were considered as the limiting factors in SMU4, similarly in SMU2 and SMU3 found to be influenced by drainage class, erosion and total nitrogen; in SMU1 soil reaction and ESP had considered as the limiting factors (Table 5).

Wheat cultivation consideration; moisture content, temperature and soil reaction were taken as influencing factors in SMU1, similarly, temperature, drainage class, topography, rooting depth to be found the limiting factors in SMU2 and SMU3. Considering sorghum crop cultivation, temperature, precipitation and total nitrogen were the limiting factors in SMU1, while topography, total nitrogen, available phosphorus, moisture and wetness were limited in rest of soil mapping units (Table 5).

Storie method revealed that SMU2, SMU3 and SMU4 were marginally suitable (S3) for the wheat and sorghum production (Figures 8,9 and Table 6) whereas SMU1 was moderately suitable. Using Square root method, all soil mapping units for the production of maize, sorghum and wheat were moderately suitable (S2) (Figures 10-12 and Table 6).

Using parametric method, maize cultivation was influenced by soil reaction and alkalinity in SMU1, similarly, wetness, erosion and total

\begin{tabular}{|c|c|c|c|}
\hline \multirow{2}{*}{ Selected mapping units } & \multicolumn{3}{|c|}{ LUTs } \\
\hline & Maize & Sorghum & Wheat \\
\hline SMU1 & $\mathrm{S} 2(\mathrm{f}, \mathrm{n})$ & $\mathrm{S} 2(\mathrm{f})$ & $\mathrm{S} 2(\mathrm{f})$ \\
\hline SMU2 & $\mathrm{S} 2(\mathrm{w}, \mathrm{f}, \mathrm{e})$ & $\mathrm{S} 2(\mathrm{w}, \mathrm{f}, \mathrm{e})$ & $\mathrm{S} 2(\mathrm{w}, \mathrm{f}, \mathrm{r})$ \\
\hline SMU3 & $\mathrm{S} 2(\mathrm{w}, \mathrm{f}, \mathrm{e})$ & $\mathrm{S} 2(\mathrm{w}, \mathrm{f}, \mathrm{e})$ & $\mathrm{S} 2(\mathrm{w}, \mathrm{e}, \mathrm{r})$ \\
\hline SMU4 & $\mathrm{S} 2(\mathrm{w}, \mathrm{n}, \mathrm{e})$ & $\mathrm{S} 2(\mathrm{w}, \mathrm{f}, \mathrm{e})$ & S3 (e) \\
\hline \multicolumn{4}{|c|}{ 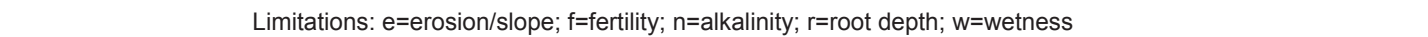 } \\
\hline
\end{tabular}

Table 3: Environmental suitability evaluation based on FAO approach.

\begin{tabular}{|c|c|c|c|c|c|c|c|c|c|c|c|c|}
\hline \multirow{4}{*}{$\begin{array}{l}\text { Selected } \\
\text { mapping } \\
\text { units }\end{array}$} & \multicolumn{12}{|c|}{ Land Utilization Types } \\
\hline & \multicolumn{4}{|c|}{ Maize } & \multicolumn{4}{|c|}{ Sorghum } & \multicolumn{4}{|c|}{ Wheat } \\
\hline & \multicolumn{2}{|c|}{ Storie } & \multicolumn{2}{|c|}{ Square root } & \multicolumn{2}{|c|}{ Storie } & \multicolumn{2}{|c|}{ Square root } & \multicolumn{2}{|c|}{ Storie } & \multicolumn{2}{|c|}{ Square root } \\
\hline & Land list & Land rank & Land list & Land rank & Land list & Land rank & Land list & $\begin{array}{l}\text { Land } \\
\text { rank }\end{array}$ & $\begin{array}{l}\text { Land } \\
\text { list }\end{array}$ & Land rank & $\begin{array}{l}\text { Land } \\
\text { list }\end{array}$ & Land rank \\
\hline SMU1 & 69 & $\mathrm{~S} 2(\mathrm{f}, \mathrm{n})$ & 75 & S2 (f,n) & 73 & S2 (f) & 79 & $\mathrm{~S} 1$ (f) & 74 & $\mathrm{~S} 2(\mathrm{e}, \mathrm{f}, \mathrm{n}, \mathrm{r})$ & 84 & $S 1(e, f, n, r)$ \\
\hline SMU2 & 58 & $\mathrm{~S} 2(\mathrm{e}, \mathrm{f}, \mathrm{w})$ & 70 & $\mathrm{~S} 2(\mathrm{e}, \mathrm{f}, \mathrm{w})$ & 50 & $\mathrm{~S} 2(\mathrm{e}, \mathrm{f}, \mathrm{w})$ & 65 & $\mathrm{~S} 2(\mathrm{e}, \mathrm{f}, \mathrm{w})$ & 69 & $\mathrm{~S} 2(\mathrm{e})$ & 77 & S1 (e) \\
\hline SMU3 & 62 & $\mathrm{~S} 2(\mathrm{e}, \mathrm{f})$ & 67 & $\mathrm{~S} 2(\mathrm{e}, \mathrm{f})$ & 53 & $\mathrm{~S} 2(\mathrm{e}, \mathrm{f})$ & 67 & $\mathrm{~S} 2(\mathrm{e}, \mathrm{f})$ & 66 & $\mathrm{~S} 2(\mathrm{e})$ & 75 & $\mathrm{~S} 2(\mathrm{e})$ \\
\hline SMU4 & 65 & $\mathrm{~S} 2(\mathrm{e}, \mathrm{n})$ & 74 & S2 $(e, n)$ & 53 & $\mathrm{~S} 2(\mathrm{e}, \mathrm{f})$ & 67 & $\mathrm{~S} 2(\mathrm{e}, \mathrm{f})$ & 62 & S2 (e) & 73 & S2 (e) \\
\hline
\end{tabular}

Table 4: Environmental suitability evaluation based on parametric method. 


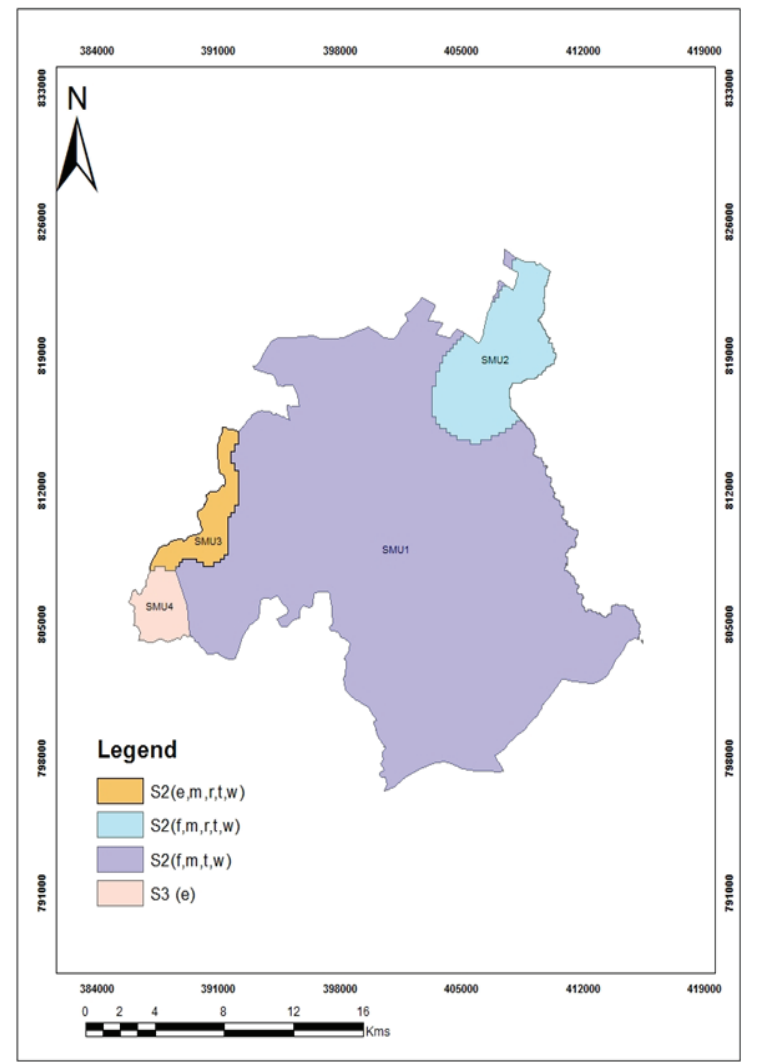

Figure 5: Land suitability map of the selected SMUs maize crop based on FAO approach Bilate Alaba Sub-watershed.

\begin{tabular}{|c|c|c|c|c|c|c|c|c|c|c|c|c|}
\hline \multirow{3}{*}{$\begin{array}{c}\text { Soil } \\
\text { mapping } \\
\text { unit }\end{array}$} & \multicolumn{12}{|c|}{ Land utilization types } \\
\hline & \multicolumn{4}{|c|}{ Maize } & \multicolumn{4}{|c|}{ Wheat } & \multicolumn{4}{|c|}{ Sorghum } \\
\hline & $\begin{array}{l}\text { Climate } \\
\text { suitability }\end{array}$ & $\begin{array}{c}\text { Soil } \\
\text { suitability }\end{array}$ & $\begin{array}{c}\text { Actual } \\
\text { suitability }\end{array}$ & Potential & $\begin{array}{l}\text { Climate } \\
\text { suitability }\end{array}$ & $\begin{array}{c}\text { Soil } \\
\text { suitability }\end{array}$ & $\begin{array}{c}\text { Actual } \\
\text { suitability }\end{array}$ & Potential & $\begin{array}{l}\text { Climate } \\
\text { suitability }\end{array}$ & $\begin{array}{c}\text { Soil } \\
\text { suitability }\end{array}$ & $\begin{array}{c}\text { Actual } \\
\text { suitability }\end{array}$ & Potential \\
\hline SMU1 & S1 & $\mathrm{S} 2(\mathrm{f}, \mathrm{n})$ & $\mathrm{S} 2(\mathrm{f}, \mathrm{n})$ & S1 & $\mathrm{s} 2(\mathrm{~m}, \mathrm{t})$ & $\mathrm{S} 2(\mathrm{f}, \mathrm{w})$ & $\mathrm{S} 2(\mathrm{f}, \mathrm{m}, \mathrm{t}, \mathrm{w})$ & $\mathrm{S} 2(\mathrm{~m})$ & $\mathrm{s} 2(\mathrm{~m}, \mathrm{t})$ & $\mathrm{S} 2(\mathrm{f}, \mathrm{m})$ & $\mathrm{S} 2(\mathrm{f}, \mathrm{m}, \mathrm{t})$ & $\mathrm{S} 2(\mathrm{~m})$ \\
\hline SMU2 & S1 & $S 2(e, f, w)$ & $S 2(e, f, w)$ & S2(e) & $\mathrm{s} 2(\mathrm{~m}, \mathrm{t})$ & $\mathrm{S} 2(\mathrm{f}, \mathrm{m}, \mathrm{r}, \mathrm{w})$ & $\mathrm{S} 2(\mathrm{f}, \mathrm{m}, \mathrm{r}, \mathrm{t}, \mathrm{w})$ & $\mathrm{S} 2(\mathrm{~m})$ & $\mathrm{s} 2(\mathrm{~m}, \mathrm{t})$ & $\mathrm{S} 2(\mathrm{e}, \mathrm{f}, \mathrm{m}, \mathrm{w})$ & $\mathrm{s} 2(\mathrm{e}, \mathrm{f}, \mathrm{m}, \mathrm{t}, \mathrm{w})$ & $\mathrm{S} 2(\mathrm{e}, \mathrm{m})$ \\
\hline SMU3 & S1 & $\mathrm{S} 2(\mathrm{e}, \mathrm{f}, \mathrm{w})$ & $\mathrm{S} 2(\mathrm{e}, \mathrm{f}, \mathrm{w})$ & $\mathrm{S} 2(\mathrm{e})$ & $\mathrm{S} 2(\mathrm{~m}, \mathrm{t})$ & $\mathrm{S} 2(\mathrm{e}, \mathrm{r}, \mathrm{w})$ & $\mathrm{S} 2(\mathrm{e}, \mathrm{m}, \mathrm{r}, \mathrm{t}, \mathrm{w})$ & $\mathrm{S} 2(\mathrm{e}, \mathrm{m})$ & $\mathrm{s} 2(\mathrm{~m}, \mathrm{t})$ & $\mathrm{S} 2(\mathrm{e}, \mathrm{f}, \mathrm{m}, \mathrm{w})$ & $\mathrm{S} 2(\mathrm{e}, \mathrm{f}, \mathrm{m}, \mathrm{t}, \mathrm{w})$ & $\mathrm{S} 2(\mathrm{e}, \mathrm{m})$ \\
\hline SMU4 & $\mathrm{S} 1$ & $\mathrm{~S} 2(\mathrm{e}, \mathrm{n}, \mathrm{w})$ & $\mathrm{S} 2(\mathrm{e}, \mathrm{n}, \mathrm{w})$ & S2(e) & $\mathrm{s} 2(\mathrm{~m}, \mathrm{t})$ & S3(e) & S3(e) & S3(e) & $\mathrm{s} 2(\mathrm{~m}, \mathrm{t})$ & $\mathrm{S} 2(\mathrm{e}, \mathrm{f}, \mathrm{m}, \mathrm{w})$ & $\mathrm{s} 2(\mathrm{e}, \mathrm{f}, \mathrm{m}, \mathrm{t}, \mathrm{w})$ & $\mathrm{S} 2(\mathrm{e}, \mathrm{m})$ \\
\hline
\end{tabular}

Table 5: Final Land suitability evaluation for the selected SMUs based on FAO approach.

nitrogen found to be influenced in SMU2, whereas total nitrogen and erosion were influenced in SMU3 and SMU4 were due to erosion and alkalinity (Table 6 and Figure 13). SMU1 was influenced by temperature and total nitrogen for sorghum cultivation, while SMU2 and SMU3 found to be limited by rainfall, erosion, total nitrogen, phosphorus and wetness; SMU4 was limited by rainfall, total nitrogen, phosphorus content and erosion (Table 6). Wheat cultivation was affected by LGP and temperature in SMU1 and SMU2, while erosion and LGP were influenced by SMU3 and SMU4 (Table 6).

\section{Discussion}

The low and unevenly distributed rain had contributed for a reduced amount of crop production as it was reported [45] sandy loam texture was also the major limiting factors for crop production. On the other study, the climate does not generally make much limitation for the cultivation of maize [46]. However, the maximum limitation method was found to be the best method compared with the parametric approach for wheat cultivation [47]. While the Square root method was suggested better result in comparison with storie and limitation method for land evaluation purposes in elsewhere [48,49].

According to [50] physical soil properties mainly soil texture was the limiting factor for wheat; maize production was affected by low humidity sunshine hour, and soil salinity and alkalinity [46]. Slope gradient, altitude, temperature, length of growing period, available water capacity, total nitrogen, available phosphorus and soil organic carbon were found the main limiting factors affected cultivation of sorghum crop in northern semi-arid Ethiopia [51].

Sorghum production in western Ethiopia was influenced by shallow depth, limited amounts of total nitrogen and available phosphorus [4] while organic carbon and soil depth were major limiting factors in Nigeria made the region permanently unsuitable for sorghum growing [52]. According to [41] available phosphorus and total nitrogen were influenced sorghum cultivation in Tanzania. Climatic factors (temperature and precipitation) were taken as major limiting factors in suitability sub watershed for sorghum production [53], length of growing period affected the crop production, and selection of crop 


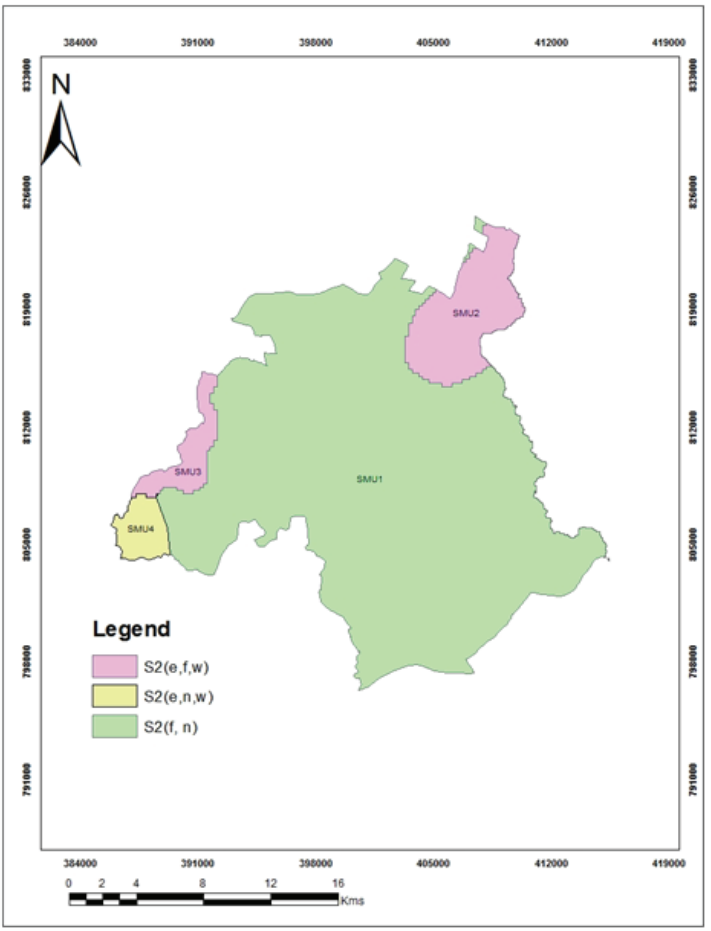

Figure 6: Land suitability map of the selected SMUs maize crop based on FAO approach Bilate Alaba Sub-watershed.

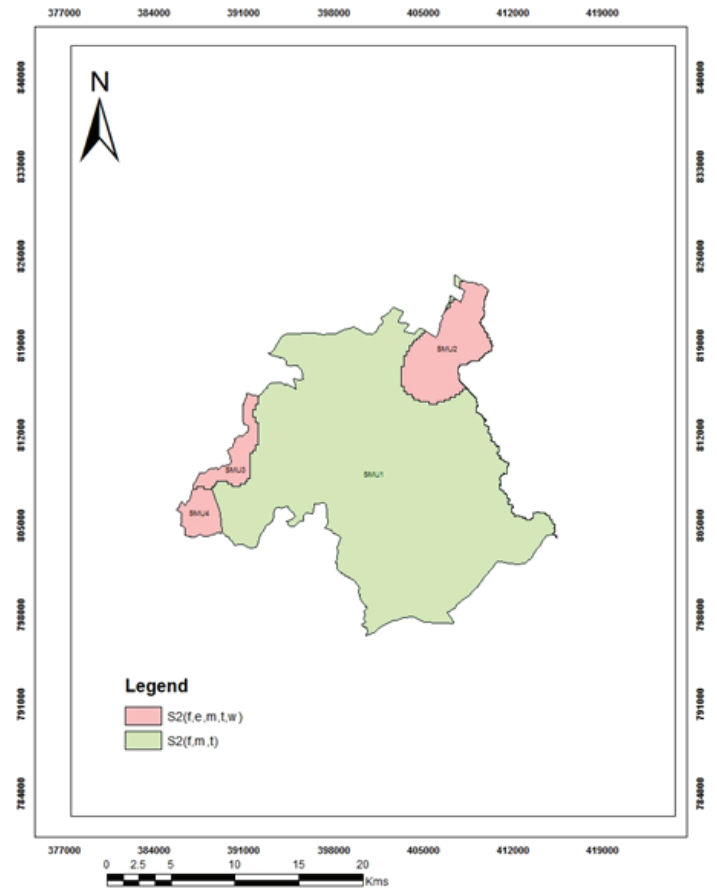

Figure 7: Land suitability map of the selected SMUs for sorghum crop based on FAO approach at Bilate Alaba Sub-watershed.

varies which matured in very short period is appropriate intervention [54].

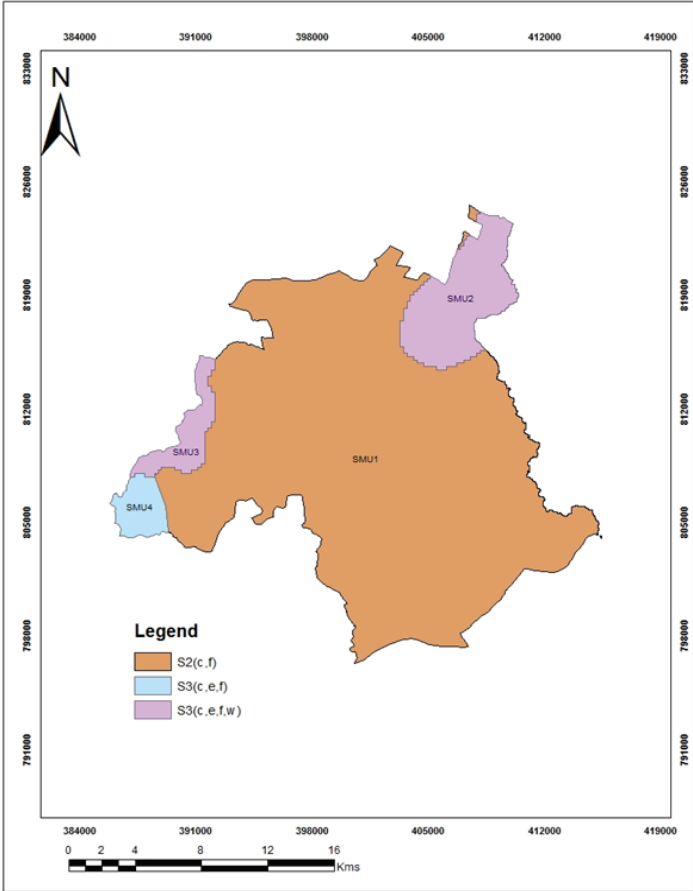

Figure 8: Land suitability map of the selected SMUs for sorghum crop using parametric Storie method at Bilate Alaba Sub-watershed.

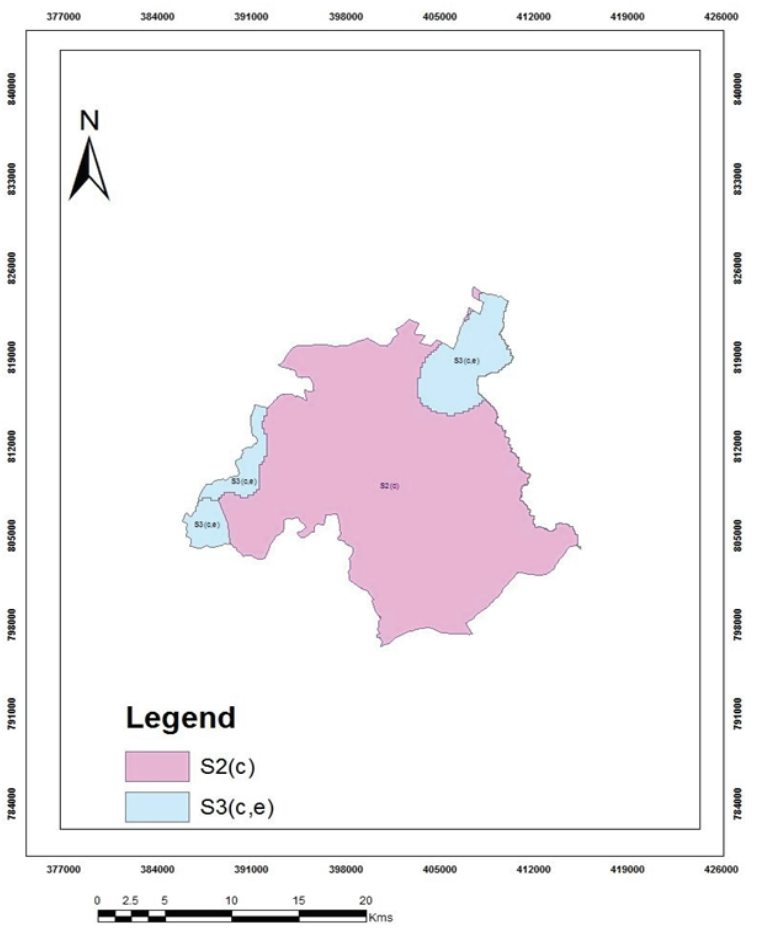

Figure 9: Land suitability map of the selected SMUs for wheat crop using parametric Storie method at Bilate Alaba Sub-watershed.

According to [55] soil erosion, soil wetness and soil fertility status were the main limiting factors affecting land quality within the Gerado catchment, North-Eastern Ethiopia for the wheat and maize production. Total nitrogen and available phosphorus are influenced by sorghum 
Citation: Mathewos M, Dananto M, Erkossa T, Mulugeta G (2018) Parametric Land Suitability Assessment for Rainfed Agriculture: The Case of Bilate Alaba Sub-watershed, Southern Ethiopia. Agrotechnology 7:183. doi: 10.4172/2168-9881.1000183

Page 8 of 11

\begin{tabular}{|c|c|c|c|c|c|c|c|c|c|c|c|c|c|c|}
\hline \multirow{4}{*}{$\begin{array}{c}\text { Soil } \\
\text { mapping } \\
\text { unit }\end{array}$} & \multicolumn{12}{|c|}{ Land utilization types } & & \\
\hline & \multicolumn{4}{|c|}{ Maize } & \multicolumn{4}{|c|}{ Sorghum } & \multicolumn{4}{|c|}{ Wheat } & \multirow{2}{*}{\multicolumn{2}{|c|}{ Area coverage }} \\
\hline & \multicolumn{2}{|c|}{ Storie } & \multicolumn{2}{|c|}{ Square root } & \multicolumn{2}{|c|}{ Storie } & \multicolumn{2}{|c|}{ Square root } & \multicolumn{2}{|c|}{ Storie } & \multicolumn{2}{|c|}{ Square root } & & \\
\hline & $\begin{array}{l}\text { Land } \\
\text { list }\end{array}$ & Land rank & $\begin{array}{l}\text { Land } \\
\text { list }\end{array}$ & Land rank & $\begin{array}{c}\text { Land } \\
\text { list }\end{array}$ & Land rank & $\begin{array}{l}\text { Land } \\
\text { list }\end{array}$ & Land rank & $\begin{array}{l}\text { Land } \\
\text { list }\end{array}$ & Land rank & $\begin{array}{l}\text { Land } \\
\text { list }\end{array}$ & Land rank & ha & $\%$ \\
\hline SMU1 & 59 & $\mathrm{~S} 2(\mathrm{f})$ & 71 & $\mathrm{~S} 2(\mathrm{f})$ & 53 & $S 2(c, f)$ & 62 & $S 2(c, f)$ & 53 & S2(c) & 60 & S2(c) & 34351 & 85.25 \\
\hline SMU2 & 50 & $\mathrm{~S} 2(\mathrm{e}, \mathrm{f}, \mathrm{w})$ & 65 & $\mathrm{~S} 2(\mathrm{e}, \mathrm{f}, \mathrm{w})$ & 36 & S3(c,e,f,w) & 51 & $\mathrm{~S} 2(\mathrm{c}, \mathrm{e}, \mathrm{f}, \mathrm{w})$ & 48 & S3(c,e) & 71 & $\mathrm{~S} 2(\mathrm{c}, \mathrm{e})$ & 3703 & 9.19 \\
\hline SMU3 & 53 & $\mathrm{~S} 2(\mathrm{e}, \mathrm{n})$ & 67 & $\mathrm{~S} 2(\mathrm{e}, \mathrm{n})$ & 38 & S3(c,e,f,w) & 52 & $\mathrm{~S} 2(\mathrm{c}, \mathrm{e}, \mathrm{f}, \mathrm{w})$ & 45 & S3(c,e) & 69 & $\mathrm{~S} 2(\mathrm{c}, \mathrm{e})$ & 1255 & 3.11 \\
\hline SMU4 & 56 & $\mathrm{~S} 2(\mathrm{e}, \mathrm{n})$ & 69 & $\mathrm{~S} 2(\mathrm{e}, \mathrm{n})$ & 38 & $S 3(c, e, f)$ & 52 & $S 2(c, e, f)$ & 45 & S3(c,e) & 69 & $\mathrm{~S} 2(\mathrm{c}, \mathrm{e})$ & 987 & 2.45 \\
\hline
\end{tabular}

Table 6: Final Land suitability evaluation for the selected SMUs based on parametric method.

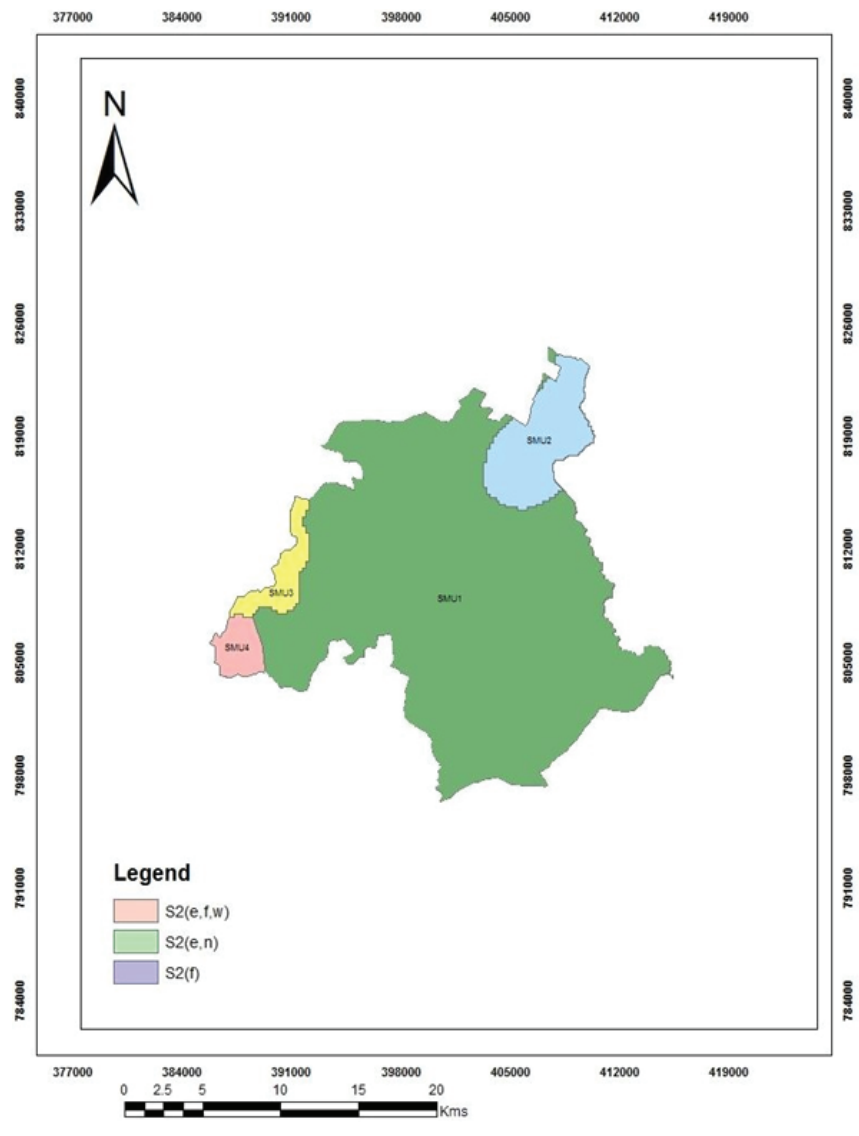

Figure 10: Land suitability map of the selected SMUs for maize crop using parametric Square root method at Bilate Alaba Sub-watershed.

production in Tanzania [41]. Soil depth, wetness and soil fertility were the main limiting factors for the production of maize in Abobo of western Ethiopia [4]. The study conducted by [56] showed that low fertility status, $\mathrm{pH}$ and topographic factors contributed to low maize productivity in Jello watershed, this also indicated that such lands can be degraded and easily lose the productive potential if the existing land use practices are ongoing. Shallow soil depth and low water holding capacity of the soil were influenced for the maize production in Yigossa Watershed, Northwestern Ethiopia; in terms of area coverage, $44.59 \%$ of the soils were found to be unsuitable for this crop [57].

The study conducted in Andit Tid watershed by [58] reported that $90.56 \%$ of the watershed was moderately suitable for wheat production, [59] reported that $46 \%$ of the Anjeni watershed highly suitable for the wheat crop. On the other hand, only $3 \%$ of the land estimated as highly suitable for the wheat cultivation in Awulaelo District in Tigray [60]. In another study by [61] 20.5\% of Wogdie District, South Wollo was

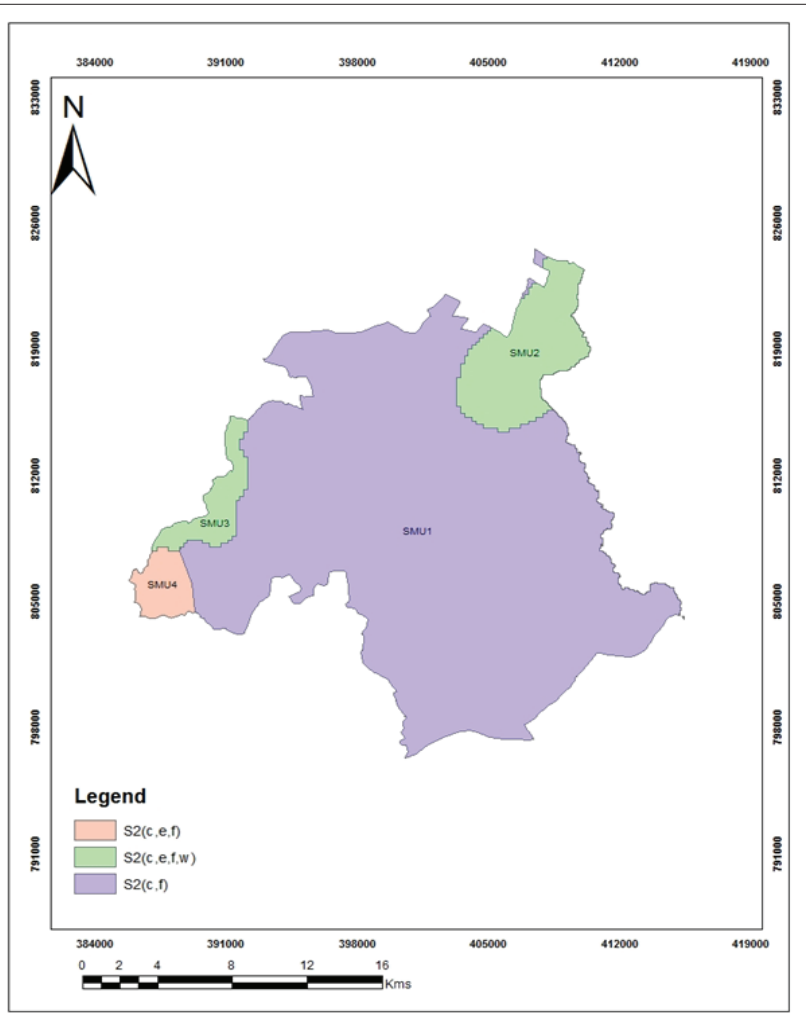

Figure 11: Land suitability map of the selected SMUs for sorghum crop using parametric Square root method at Bilate Alaba Sub-watershed.

classified as moderately suitable and $79.5 \%$ marginally suitable for wheat in South Wello while [56] reported that $61 \%$ of the land was not suitable for wheat production and 6\% moderately suitable and 33\% marginally suitable for wheat crop in Jello watershed, Eastern Ethiopian highland. $40 \%$ of Anjeni watershed were moderately suitable for maize production [59] while $50.28 \%$ of the area was marginally suitable for maize cropping while $24.34 \%$ was highly suitable and $6.34 \%$ was moderately suitable in Iran with limitations reported were low organic matter, total nitrogen and soil $\mathrm{pH}[62]$.

Due to the fact that interrelation interaction of all-around influences of the land properties by Storie approach land index leads to overestimation of the land classes obtained compared to what gained through FAO and Square root methods. The result obtained by maximum limitation was different from the parametric method because of multiplication of every land characteristics by other lower classes in parametric method (Table 6). In comparison with other methods, square root approach has resulted possibly more reasonable as reported by scholars $[63,64]$. 


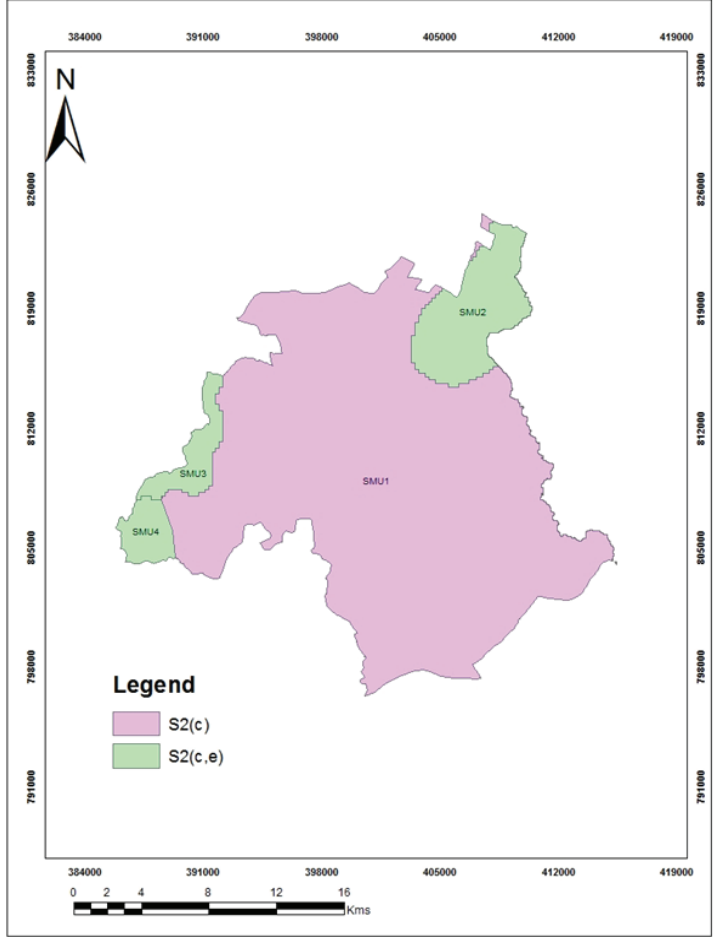

Figure 12: Land suitability map of the selected SMUs for wheat crop using parametric Square root method at Bilate Alaba Sub-watershed.

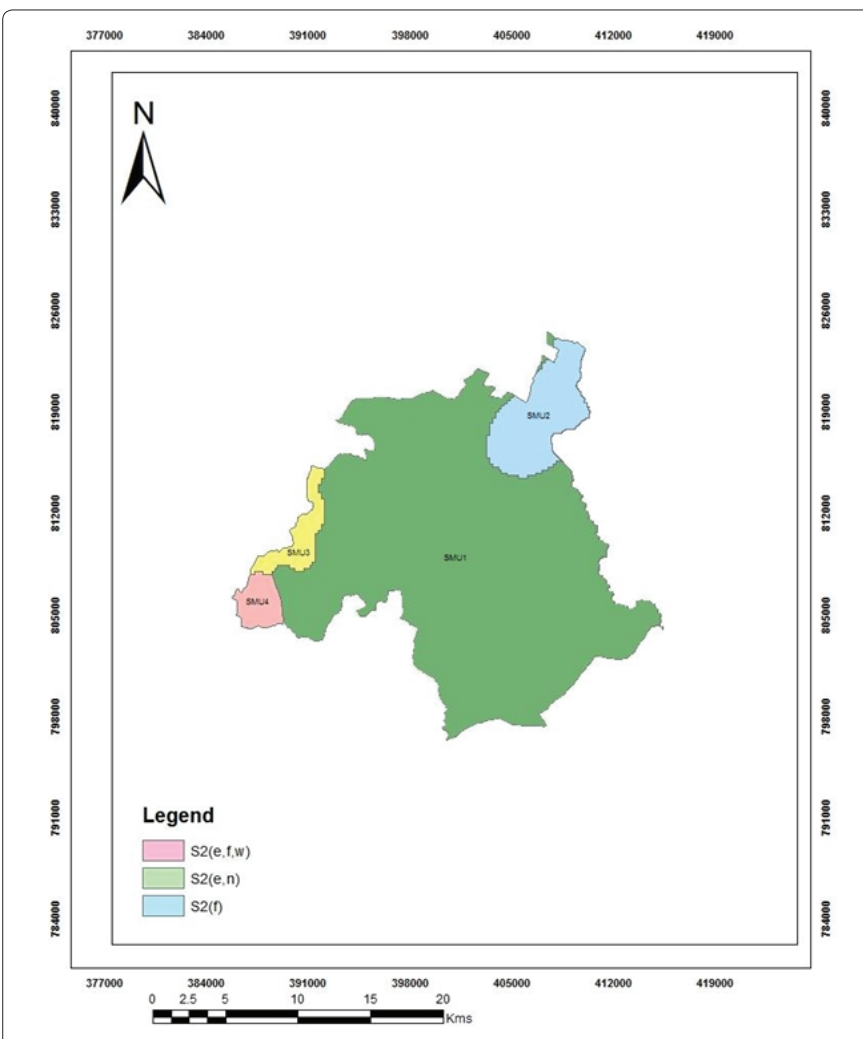

Figure 13: Land suitability map of the selected SMUs for maize crop using parametric Storie method at Bilate Alaba Sub-watershed.

\section{Conclusion}

Generally, the sub-watershed was highly suitable (S1) from the climatic point of view for maize production, moderately suitable (S2) for wheat and sorghum cultivation. The overall land suitability assessment of the study showed significant differences among the identified soil mapping units for the three major crops. Soil fertility, moisture, precipitation, temperature and soil depth found to be the limiting factors based on the FAO method; and similar results obtained by Storie and Square root approach with few exceptions. Soil management practices may improve the problem of soil fertility including an application of animal manures and household wastes for nitrogen and phosphorus limitations. For the topographic feature which was affected land suitability, proper soil and water conservation measures to be applied for the effects of erosion. FAO and Square root method seem realistic compared with Storie index which overestimated the land suitability values $[49,63]$. Land index values in Square Root method were higher than Storie method. It was suggested by various scholars [63-66] Square root methods showed real outcomes which were compared with Storie index.

This study used only biophysical parameters for land evaluation analysis; future studies could include environmental and socioeconomic variables, together with computer aid technologies (Multi-Criteria Decision Analysis and Analytical Hierarchy Process) to improve the suitability classes for lower classes.

\section{Acknowledgment}

The authors would like to acknowledge Agriculture and Natural Resource Development Office of the Alaba Special District and farmers supported in data collection at field level.

\section{References}

1. FAO (2007) Land evaluation, towards a revised framework. Land and Water Discussion Paper 6. Rome, Italy.

2. Sys I, Van Ranst E, Debaveye J (1991a) Land evaluation. Part I. Principles in land evaluation and crop production calculations. Agricultural publication, No.7, General Administration for Development Cooperation. Brussels, Belgium

3. FAO (1985) Guidelines: Land evaluation for irrigated agriculture. FAO soils bulletin 55 .

4. Teshome Y, Kibebew K, Heluf G, Sheleme B (2013) Physical land suitability evaluation for rainfed production of cotton, maize, upland rice and sorghum in Abobo area, Western Ethiopia. American journal of research and communication 1: 296-318

5. Sys C (1979) Evaluation of the physical environment for irrigation in terms of land characteristics and land qualities. World Soil Resourced report (FAO). no. 50. Rome.

6. Shahbazi F, Jafarzedeh AA, Saramadian F, Neyeshaboum MR, Qustan S, et al. (2009) Climate change impacts on land capability using microLEIS DSS. Int Agrophysics 23: 277-286.

7. Elaalem M, Comber A, Fisher P (2011) A comparison of fuzzy AHP and ideal point methods for evaluating land suitability. Transactions in GIS 15: 329-346.

8. Tang H, Debaveye J, Ruan D, Van Ranst E (1991) Land suitability classification based on fuzzy set theory. Pedology 3: 277-290.

9. FAO (1976) Framework for Land Evaluation. FAO Soil Bulletin No.32, FAO, Rome.

10. Ali K, Ferendoon S, Ahmad H, Mahmoud O (2010) Land suitability evaluation using fuzzy continuous classification, A case study: Ziaran region. Mod Appl Sci 7: 72-81.

11. Rabia A, Terribile $F$ (2013) Introducing a new parametric concept for land suitability assessment. IJESD 1: 15-19.

12. Sarvari SA, Mahmoudi SH (2001) Qualitative land suitability evaluation for 
Citation: Mathewos M, Dananto M, Erkossa T, Mulugeta G (2018) Parametric Land Suitability Assessment for Rainfed Agriculture: The Case of Bilate Alaba Sub-watershed, Southern Ethiopia. Agrotechnology 7:183. doi: 10.4172/2168-9881.1000183

irrigated sugar beet in Ghazvin region. IJSWR Special issue on soil survey land evaluation pp. 66-74

13. Jafarzadeh AA, Momtaz HR, Neyshabouri MR (2005) Qualitative evaluation of land in Karaj research station of Tabriz University for wheat, potato, maize tomato, bean and alfalfa. In: Int. Conference of ICEM, Hyderabad, India pp. 95-102.

14. Osie BA (1993) Evaluation of some soils in south-western Nigeria for arable crop production. Soil Sci Plant Anal 24: 757-773.

15. Embrechts J, Zulkanian P, Sys C (1988) Physical land evaluation using a parametric method. Application to oil palm plantation in north-sumatra, Indonesia. SSL 8: 111-122.

16. Burrough PA (1996) In J. Bouma: Discussion of paper by D.G. Rossiter. Geoderma, 72: 191-202.

17. Nahusenay A, Kibebew K (2015) Land suitability evaluation in Wadla Delanta Massif of north central highlands of Ethiopia for rainfed crop production. Afr $J$ Agr Res 10: 1595-1611

18. Esa E, Assen M (2017) A GIS based land suitability analysis for sustainable agricultural planning in Gelda catchment, Northwest Highlands of Ethiopia. JGRP 10: 77-91.

19. Taffesse AS, Dorosh P, Asrat S (2012) Crop production in Ethiopia: Regional patterns and trends (ESSP II Working Paper 16). International Food Policy Research Institute (IFPRI). In Ethiopia Strategy Support Program (ESSP II), University of Pennsylvania, Philadelphia USA.

20. Teshome M (2014) Population growth and cultivated land in rural Ethiopia: Land use dynamics, access, farm size, and fragmentation. Res Environ 4: 148-161.

21. Mekuriaw A (2017) Assessing the effectiveness of land resource management practices on erosion and vegetative cover using GIS and remote sensing techniques in Melaka watershed, Ethiopia. Environ Syst Res 6: 1-10.

22. Abegaz A, Winowiecki LA, Vågen TG, Langan S, Smith JU (2016) Spatial and temporal dynamics of soil organic carbon in landscapes of the upper Blue Nile basin of the Ethiopian highlands. Agr Ecosyst Environ 218: 190-208.

23. Fischer G, Velthuizen HV, Shah M, Nachtergaele F (2002) Global agroecological assessment for agriculture in the 21st Century: Methodology and results. Int Inst Appl Syst Analys Laxenburg, Australia. Food and Agriculture Organization of the United Nations Rome, Italy.

24. Fresco LO, Huizing H, Van Keulen H, Luning HA, Schipper RA (1992) Land evaluation and farming systems analysis for land- use planning. FAO guidelines: Working document, ITC and Wageningen Agricultural University, Wageingen, The Netherlands pp.1-290.

25. IPMS (2005) Alaba pilot learning woreda diagnosis and program design pp. $1-92$.

26. FAO (1998) The Soil and terrain database for northeastern Africa, CD from Sales and Marketing Group FAO, Italy.

27. Walkley A, CA Black (1934) An examination of degtjarff method for determining soil organic matter and proposed modification of the chromic acid titration method. Soil sci 37: 29-38.

28. Jackson ML (1958) Soil chemical analysis. Prentice Hall, Inc, Engle Wood Cliffs New Jersy, USA 582p.

29. Olsen SR, CV Cole, FS Watanabe, Dean LA (1954) Estimation of available phosphorus in soils by extraction with sodium bicarbonate. USDA Pp. 1-19.

30. Bouyoucos GJ (1962) Hydrometer method improved for making particle size analyses of soils. AJ 54: 464-465.

31. Chapman HD (1965) Cation exchange capacity. In: Black, CA, Ed, Methods of Soil Analysis, ASA, Madison 891-901.

32. Sahlemedhin S, Taye B (2000) Procedures for soil and plant analysis. Nationa soil research center, EARO, technical paper no. 74, Addis Abeba, Ethiopia p. 110

33. Van Reeuwijk (1993) Procedures for soil analysis. 4th ed. International Soil Reference and Information Center, Netherlands.

34. FAO (1983) Guidelines: Land evaluation for rain-fed agriculture. Soil Bulletin no. 52, FAO, Rome.

35. Sys C, Van Ranst E, Debaveye J (1991b) Land evaluation. Part II. Methods in land evaluation. Agriculture publications, No.7, GADC, Brussels, Belgium.
36. Sys C, Van Ranst E, Debaveye J, Beernaert F (1993) Land evaluation. Part III. Agriculture Publication No.7, GADC, Brussels, Belgium 191p.

37. Henok M (2010) Land suitability and crop suitability analysis using remote sensing and GIS application; a case study in Legambo woreda, Ethiopia. Department of Earth Sciences, Addis Ababa University, Ethiopia pp.1-70.

38. Kassa T, Mulu H (2012) Land suitability characterization for crop and fruit production in midlands of Tigray, Ethiopia. Department. MEJS 4: 64-76.

39. Van Diepen CA, Van Keulen H, Wolf J, Berkhout JA (1991) Land evaluation: From intuition to quantification. In: B.A. Stewart (ed.), Advances in Soil Science 15: 139-204.

40. Alem H, Kibebew K, Heluf G (2015) Land suitability evaluation for rainfed production of barley and wheat at Kabe Sub- watershed, Northeastern Ethiopia. Afr J Soil Sci 3: 147-156.

41. Kaaya AK, Msanya BM, Mrema JP (1994) Soils and land evaluation of part of the Sokoine University of agriculture farm(Tanzania) for some crops under rainfed conditions. Afr Stud Monogr 15: 97-117.

42. Martin S (1992) CROPWAT: A computer programme for irrigation planning and management. FAO land and Water Development Division, Rome, Italy.

43. Storie R (1978) Storie index soil rating Oakland: Division of Agriculture Sciences, University of California, Special Publication 3203

44. Khiddir SM (1986) A statistical approach in the use of parametric systems applied to the FAO framework for land evaluation. State University Gent Belgium 141pp.

45. Yemane M, Kebede F, Mekuria W (2015) Application of different land evaluation methods for Faba Bean (Vicia Faba) production suitability assessment for central Tigray, Ethiopia. Journal of the dry lands 2: 15-24.

46. Taati A, Sarmadian F (2015) Qualitative land suitability evaluation for maize (Zea mais L) in Abyek, Iran Using FAO Method. GJRR 2: 37-44.

47. Sharififar A (2012) Assessment of different methods of soil suitability classification for wheat cultivation. J Agric 29: 47-54

48. Khordebin S, Landi A (2011) Comparison of the land qualitative suitability with the use of FAO method and ales model for major crops in Sardasht of Behbahan Khuzestan Province, Iran. MEJSR 10: 477-481.

49. Vargahan B, Shahbazi F, Hajrasouli M (2011) Quantitative and qualitative land suitability evaluation for maize cultivation in Ghobadlou Region, Iran. Ozean J Appl Sci 4: 1943-2429.

50. Albaji M, Alboshokeh A (2017) Assessing agricultural land suitability in the Fakkeh region, Iran.Outlook Agr 46: 57-65.

51. Kahsay A, Haile M, Gebresamuel G, Mohammed M (2018) Land suitability analysis for sorghum crop production in northern semi-arid Ethiopia: Application of GIS-based fuzzy AHP approach. Cogent Food Agric 4: 1-24.

52. Ahmed M, Jeb DN (2014) Land suitability for sorghum using multicriteria evaluation (MCE) and analytical hierarchy process (AHP) in Bunkure Kano State, Nigeria. IOSR-JAVS 7: 2319-2380.

53. Mohan MM (2008) Characterization and classification of soils and land suitability of a micro-watershed in Hanagal taluk. Department of Soil science and Agricultural Chemistry, UAS, Dharwad, India pp 1-17

54. Yizengaw T (1994) An approach towards a macro scale land evaluation as a basis to identify resource management options in central Ethiopia. University of Gent, Belgium.

55. Bahir AL, Ahmed MA, Antille DL (2015) Land suitability evaluation to optimize land management of small-scale farms in the Gerado catchment, North-Eastern Ethiopia. Trop Agric 92: 49-68.

56. Girma R, Moges A, Quraishi S (2015) GIS based physical land suitability evaluation for crop production in Eastern Ethiopia: A case study in Jello watershed. Agrotechnology 5: 139-145.

57. Yihenew G, Gizachew A, Eyasu E, Mekonnen G (2014) Soil characterization and land suitability evaluation to cereal crops in Yigossa Watershed, Northwestern Ethiopia. J Agr Sci 6: 199-206.

58. Yohannes H, Soromessa T (2018) Land suitability assessment for major crops by using GIS-based multi-criteria approach in Andit Tid watershed, Ethiopia. Cogent Food Agric 4: 1-28.

59. Alemu WG, Amare T, Yitaferu B, Selassie YG, Wolfgramm B, et al. (2013) 
Citation: Mathewos M, Dananto M, Erkossa T, Mulugeta G (2018) Parametric Land Suitability Assessment for Rainfed Agriculture: The Case of Bilate Alaba Sub-watershed, Southern Ethiopia. Agrotechnology 7:183. doi: 10.4172/2168-9881.1000183

Impacts of soil and water conservation on land suitability to crops: The case of Anjeni Watershed, Northwest Ethiopia. J Agr Sci 5: 95-109.

60. Rabia AH (2012) A GIS based land suitability assessment for agricultural planning in Kilte Awulaelo district, Ethiopia. In The 4th International Congress of ECSSS, EUROSOIL, Bari, Italy, soil science for the benefit of mankind and environment pp. 1257.

61. Motuma M, Suryabhagavan KV, Balakrishnan M (2016) Land suitability analysis for wheat and sorghum crops in Wogdie District, South Wollo, Ethiopia, using geospatial tools. AG 8: 57-66.

62. Mustafa AA, Man S, Sahoo RN, Nayan A, Manoj K, et al. (2011) Land suitability analysis for different crops: A multi criteria decision making approach using remote sensing and GIS. Indian Agricultural Research Institute 3: 1-24.
63. Shahbazi F, Jafarzadeh AA (2004) Qualitative evaluation of land suitability in Khushe Mehr region of Bonab for wheat, alfalfa, onion, sugar beet and maize. AS 14: 67-85.

64. Albaji M, Naseri AA, Papan P, Nasab SB (2009) Qualitative land evaluation of land suitability for principal crops in the West Shoush plain, Southwest Iran. Bulg J Agric Sci 15: 135-145.

65. Alamdari, P, Amanifar S (2016) Land suitability classification of East Azerbaijan research station for tomato, potato, onion and bean. IJAMAD 6: 117-122.

66. Malekian A, Jafarzadeh A (2011) Qualitative land suitability evaluation of the Khajeh research station for Wheat, Barley, Alfalfa, Maize and Safflower. Res Plant Biol 1: 33-40. 